\title{
Negative online reviews and webcare strategies in social media: effects on hotel attitude and booking intentions
}

The purpose of this research is to examine the effects of different webcare strategies (defensive, accommodative, no action) across two different types of social media (TripAdvisor and Twitter) on hotel attitude and booking intentions. The results of an experimental design show that negative electronic word-ofmouth (NWOM) has a negative effect on attitudes and booking intention. Moreover, the benefits derived from the type of response vary depending on the social media type in which NWOM appears. The findings also suggest that no response is worse than either defensive or accommodative responses.

Keywords: online reviews; negative word-of-mouth; social media; brand attitude; booking intention; hotel industry

\section{Introduction}

Tourists' online comments have a considerable influence on the success of tourism businesses and hence, tourism management is increasingly devising strategies to respond to these customer interventions (De Pelsmacker, van Tilburg, \& Holthof, 2018; Gössling, Hall, \& Andersson, 2018; Gössling, Zeiss, Hall, Martin-Rios, Ram, \& Grøtte, 2018; Prayag, Hall, \& Wood, 2018; Proserpio \& Zervas, 2017; Sparks \& Bradley, 2017). The strategies are especially relevant in the case of voicing complaints, also known as negative electronic word-of-mouth (NWOM) (Balaji, Khong, \& Chong, 2016). One strategy to combat the negative effects of NWOM in social media is to participate in the online conversations with consumers and to respond to consumer reviews, which is called webcare (Van Noort, Willemsen, Kerkhof, \& Verhoeven, 2015; Weitzl \& Hutzinger, 2017). In this study, we investigate the effects of negative online hotel reviews found on TripAdvisor, a travel review site (TRS), and Twitter, a social networking site (SNS), on consumer attitudes and booking intention. Furthermore, we study the effect of firms' webcare strategies in this context. 
When a set of online reviews for a hotel is predominantly negative, consumers tend to believe that the hotel performs poorly, leading them to form a negative attitude towards the hotel and decrease booking intention (Sparks \& Browning, 2011; Ye, Law, and $\mathrm{Gu}, 2009)$. Therefore, we suggest:

H1a: Negative online reviews increase the negative attitude toward the hotel.

H1b: Negative online reviews lead to a low booking intention for the hotel.

H1c: Attitude change influences booking intention.

Another important question is whether marketers should ignore or respond (webcare) to online negative comments, and whether these responses can influence consumer behavior. Prior studies categorized webcare strategies into defensive or accommodative responses (Lee \& Cranage, 2014). A defensive response is one in which the company explains the external factors that caused the service failure and does not accept fault. An accommodative response implies accepting responsibility for the fault. These strategies are expected to have different impacts on attitudes and booking intention (Audrain-Pontevia \& Kimmel, 2008; Lee \& Cranage, 2014). Accordingly, we hypothesize:

H2a: When the reviews are mostly negative, the use of defensive responses will result in a more negative attitude toward the hotel.

$\mathrm{H} 2 \mathrm{~b}$ : When the reviews are mostly negative, the use of defensive responses will result in a lower booking intention.

H2c: The effect of a defensive response on attitude toward the hotel will be stronger than the effect of an accommodative response or no response at all.

H2d: The effect of a defensive response on booking intention will be stronger than the effect of an accommodative response or no response at all. 
Finally, previous research has been conducted to understand webcare strategies in the presence of negative online reviews (e.g. Lee \& Cranage, 2014; Sparks \& Bradley, 2017; Van Noort et al., 2015). However, they do not consider that different types of social media sites may lead to different consumer responses. This study addresses an explicit call for research to better understand social media and to analyze the differential impacts of different social media sites in tourism businesses (Sotiriadis, 2017). From the wide range of social media sites, we have selected TripAdvisor and Twitter. TripAdvisor is one of the most popular travel review sites on the Internet (Xiang, Du, Ma \& Fan, 2017). Twitter is also a popular social networking site and the presence of travel and tourism companies on Twitter and the trend of people tweeting about their travel experiences is constantly growing (Kim \& Chae, 2018). Besides, consumers are more prone to use Twitter as a platform to complain, looking for a fast company reaction. Consequently, we hypothesize:

H3: When the reviews are mostly negative, the platform used to disseminate either response strategy will have a different effect on:

(a) the attitudes toward the hotel

(b) the booking intention

\section{Method}

We used a 2 (Social media) x 3 (Response strategy) between-subjects factorial experimental design. A link to the questionnaire and an invitation to participate in this study was posted online. Only those individuals who had booked a hotel online within the last 12 months were allowed to answer the survey. First, respondents were asked to imagine searching for a hotel for a week-long holiday for which they had no previous experience and situated in an unknown location. Then, they were exposed to a description of a hypothetical hotel. Once we have presented the context, respondents 
were asked to indicate their pre-attitude towards the hotel. Then, respondents were asked to read other customers' reviews of the hypothetical hotel. The hotel reviews, mostly negative and designed to mimic real reviews, were presented in six different scenarios (three response types and two social media sites). At the bottom of each set of reviews, there was either no response, an accommodative response, or a defensive response from management. Then, questions were asked to check the effectiveness of the stimulus materials, the post-attitude towards the hotel, the booking intention and the demographic profile.

Manipulation checks for valence of reviews, scenario realism and managerial responses were measured using 7-point scales as proposed by Dabholkar and Bagozzi (2002) and Lee and Cranage (2014). Attitude measurement was generated from prior studies (Ayeh, Au, \& Law, 2013) via a three-item, 7-point semantic differential scale. Booking intention was measured by asking respondents their level of intent to book a stay at the hypothetical hotel ( $1=$ strongly disagree and $7=$ strongly agree) (Spark \& Browning, 2011). 132 respondents completed the entire experiment. The majority of the respondents were women (68.2\%), aged between 25 and 34 years $(43.2 \%)$, and with university studies (97\%).

\section{Results}

The manipulation checks showed that the stimuli were effectively executed: respondents found the reviews to be more negative than positive, they felt that the scenarios were realistic, and they had no difficulty imagining the situation described. Respondents also distinguished between an accommodative and a defensive managerial response. Mean test analysis was first performed comparing pre-attitude to post-attitude considering the different scenarios and the overall sample (see Table 1). Significant differences were found, thus supporting Hypothesis 1a. 
Table 1 here

The mean values of booking intention were all equally low within the six scenarios, with mean values ranging between 2.13 and $3.22(F(5,131)=1.85, \mathrm{p}>.10)$ and, therefore, Hypothesis $1 \mathrm{~b}$ was also supported. Hypothesis 1c stated that attitude change may influence booking intention. A negative and significant Spearman's rank correlation coefficient (Attitude change vs. Booking intention=-.42, $\mathrm{p}<.01$ ) supported this hypothesis.

To test for Hypothesis 2a and Hypothesis 2c, we first compared the postattitudes for defensive responses (i.e., responses in scenarios 3 and 6) to the postattitudes for accommodative responses (i.e., responses in scenarios 2 and 5) (MScen3and6=3.41 vs. MScen2and5=3.36; two-tailed $t[85]=.16, p>.1$ ). Then, we compared the post-attitudes for defensive responses to the post-attitudes for no responses (i.e., responses in scenarios 1 and 4) (MScen3and6=3.41 vs. MScen1 and4=2.92; two-tailed $\mathrm{t}[87]=1.77, \mathrm{p}<.1$ ). No significant differences were found and therefore, Hypotheses $2 \mathrm{a}$ and $2 \mathrm{c}$ were rejected. To test Hypothesis $2 \mathrm{~b}$ and Hypothesis 2d, we first compared the booking intention for defensive responses to the booking intention for accommodative responses (MScen3and6=2.96 vs. MScen2and5=2.88; two-tailed $\mathrm{t}[85]=.23, \mathrm{p}>.1$ ). Then, we compared the booking intention for defensive responses to the booking intention for no responses (MScen3and6=2.96 vs. MScen1and4=2.47; two-tailed $\mathrm{t}[88]=1.61, \mathrm{p}>.1)$. No significant differences were found and therefore, Hypotheses $2 \mathrm{~b}$ and $2 \mathrm{~d}$ were also rejected. Oneway analysis of variance (ANOVA) and non-parametric tests confirmed that no significant differences existed between the three types of corporate responses.

Table 2 shows that post-attitudes, attitude change, and booking intentions were significantly higher in Twitter compared to TripAdvisor, thus supporting Hypothesis 3a 
and Hypothesis $3 \mathrm{~b}$. Finally, the attitude changes differed significantly contingent upon the platform and the type of managerial response (see Table 3).

Table 2 here

Table 3 here

\section{Conclusions}

Our findings show that consumers have significantly lower attitudes toward the hotel after reading a set of negatively framed online reviews. They also have very low booking intentions. The implications are straightforward, namely making sure that the core product and services meet standard quality requirements and thus minimizing the opportunity for complaints. The results also illustrate that there is a significant attitude change towards the negative comments regardless of the type of managerial response, with no response being the worst and accommodative being the best type of response (thereby alleviating the influence of negative reviews). With regards to booking intentions, no significant effects of managerial response type could be measured. Finally, webcare effects were much stronger on the TRS (TripAdvisor) where users seem less inclined to accept interventions from the company in question. Compared to tweets, which have limited information content due to the character constraint, TripAdvisor messages allow for much more detailed information. This could be another reason why consumers' responses on TripAdvisor are generally stronger than on Twitter. The implications of these findings are twofold: (1) managerial responses should consider the medium in which they are communicating and (2) with the exception of defensive responses in Twitter, accommodative responses are much better than no responses, which work poorly in both platforms. 


\section{References}

Audrain-Pontevia, A.-F., \& Kimmel, A. (2008). Negative word-of-mouth and redress strategies: An exploratory comparison of French and American managers. Journal of Customer Satisfaction, Dissatisfaction and Complaining Behavior, 21, 124-136.

Ayeh, J. K., Au, N., \& Law, R. (2013). “Do we believe in TripAdvisor?” Examining credibility perceptions and online travelers' attitude toward using user-generated content. Journal of Travel Research, 52(4), 437-452.

Balaji, M. S., Khong, K. W., \& Chong, A. Y. L. (2016). Determinants of negative wordof-mouth communication using social networking sites. Information \& Management, 53(4), 528-540.

Dabholkar, P.A., \& Bagozzi, R.P. (2002). An attitudinal model of technology-based self- service: Moderating effects of consumer traits and situational factors. Journal of the Academy of Marketing Science, 30(3), 184-202.

De Pelsmacker, P., van Tilburg, S., \& Holthof, C. (2018). Digital marketing strategies, online reviews and hotel performance. International Journal of Hospitality Management, 72, 47-55.

Gössling, S., Hall, C. M., \& Andersson, A.-C. (2018). The manager's dilemma: A conceptualization of online review manipulation strategies. Current Issues in Tourism, 21(5), 484-503.

Gössling, S., Zeiss, H., Hall, C. M., Martin-Rios, C., Ram, Y., \& Grøtte, I.-P. (2018). A cross-country comparison of accommodation manager perspectives on online review manipulation. Current Issues in Tourism, DOI: 10.1080/13683500.2018.1455171.

Kim, W. H., \& Chae, B. (2018). Understanding the relationship among resources, social media use and hotel performance: The case of twitter use by hotels. International 
Journal of Contemporary Hospitality Management, DOI: 10.1108/IJCHM-022017-0085.

Lee, C. H., \& Cranage, D. A. (2014). Toward understanding consumer processing of negative online word-of-mouth communication: The roles of opinion consensus and organizational response strategies. Journal of Hospitality \& Tourism Research, $38(3), 330-360$.

Prayag, G., Hall, C. M., \& Wood, H. (2018). I feel good! Perceptions and emotional responses of Bed \& Breakfast providers in New Zealand towards Trip Advisor. Journal of Hospitality Marketing \& Management, 27(1), 1-20.

Proserpio, D., \& Zervas, G. (2017). Online reputation management: Estimating the impact of management responses on consumer reviews. Marketing Science, 36(5), $645-665$.

Sotiriadis, M. D. (2017). Sharing tourism experiences in social media: A literature review and a set of suggested business strategies. International Journal of Contemporary Hospitality Management, 29(1), 179-225.

Sparks, B. A., \& Bradley, G. L. (2017). A "Triple A" typology of responding to negative consumer-generated online reviews. Journal of Hospitality \& Tourism Research, 41(6), 719-745.

Sparks, B. A., \& Browning, V. (2011). The impact of online reviews on hotel booking intentions and perception of trust. Tourism Management, 32(6), 1310-1323.

Van Noort, G., Willemsen, L. M., Kerkhof, P., \& Verhoeven, J. W. (2015). Webcare as an integrative tool for customer care, reputation management, and online marketing: A literature review. In Integrated Communications in the Postmodern Era (pp. 77-99). London: Palgrave Macmillan. 
Weitzl, W., \& Hutzinger, C. (2017). The effects of marketer-and advocate-initiated online service recovery responses on silent bystanders. Journal of Business Research, 80, 164-175.

Xiang, Z., Du, Q., Ma, Y., \& Fan, W. (2017). A comparative analysis of major online review platforms: Implications for social media analytics in hospitality and tourism. Tourism Management, 58, 51-65.

Ye, Q., Law, R., \& Gu, B. (2009). The impact of online user reviews on hotel room sales. International Journal of Hospitality Management, 28(1), 180-182. 
Table 1. Mean Differences between Pre-attitude and Post-attitude Measures

\begin{tabular}{lrrrrr}
\hline $\begin{array}{l}\text { Scenarios- } \\
\text { Social media channel / Webcare Response }\end{array}$ & $\mathrm{n}$ & $\begin{array}{r}\text { Preatt } \\
(\alpha=.96)\end{array}$ & $\begin{array}{r}\text { Postatt } \\
(\alpha=.96)\end{array}$ & $\begin{array}{r}\text { Attitude } \\
\text { change }\end{array}$ & t-value \\
\hline Scen 1- TripAdvisor / no response & 23 & 5.54 & 2.58 & -2.96 & $-7.42^{* * *}$ \\
Scen 2- TripAdvisor / accommodative & 19 & 5.28 & 3.02 & -2.26 & $-6.12^{* * *}$ \\
Scen 3 - TripAdvisor / defensive & 23 & 5.75 & 2.97 & -2.78 & $-6.83^{* * *}$ \\
Scen 4- Twitter / no response & 22 & 5.61 & 3.26 & -2.35 & $-7.28^{* * *}$ \\
Scen 5- Twitter / accommodative & 23 & 5.65 & 3.64 & -2.01 & $-9.45^{* * *}$ \\
Scen 6- Twitter / defensive & 22 & 5.76 & 3.86 & -1.90 & $-5.34 * * *$ \\
Total sample & 132 & 5.61 & 3.23 & -2.38 & $-16.52^{* * *}$ \\
\hline
\end{tabular}

Note: Non-parametric tests (Wilcoxon signed-rank tests) showed similar results. $* * * p<.01$ 
Table 2. Mean Differences in Post-attitudes, Attitude Change and Booking Intention by Social Media Type

\begin{tabular}{|c|c|c|c|c|c|c|}
\hline \multirow[t]{2}{*}{ Social Media Type } & \multicolumn{2}{|c|}{ Post-attitude } & \multicolumn{2}{|c|}{ Attitude change } & \multicolumn{2}{|c|}{ Booking intention } \\
\hline & Mean & S.D. & Mean & S.D. & Mean & S.D. \\
\hline TripAdvisor $(\mathrm{n}=65)$ & 2.85 & 1.31 & -2.69 & 1.81 & 2.48 & 1.30 \\
\hline Twitter $(n=67)$ & 3.59 & 1.28 & -2.08 & 1.41 & 3.04 & 1.48 \\
\hline t-test (p-value) & \multicolumn{2}{|c|}{$-3.26(.00)$} & \multicolumn{2}{|c|}{$-2.13(.04)$} & \multicolumn{2}{|c|}{$-2.34(.02)$} \\
\hline Mann-Whitney U & \multicolumn{2}{|c|}{1449.00} & \multicolumn{2}{|c|}{1702.50} & \multicolumn{2}{|c|}{1694.50} \\
\hline W-Wilcoxon & \multicolumn{2}{|c|}{3529.00} & \multicolumn{2}{|c|}{3718.50} & \multicolumn{2}{|c|}{3839.50} \\
\hline Z (Prob > Z) & \multicolumn{2}{|c|}{$-3.23(.00)$} & \multicolumn{2}{|c|}{$-1.91(.05)$} & \multicolumn{2}{|c|}{$-2.25(.02)$} \\
\hline
\end{tabular}


Table 3. Mean Differences in Post-attitudes, Attitude Change and Booking Intention by Response Type and Social Media Type

\begin{tabular}{llllllllll}
\hline \multirow{2}{*}{ Webcare Response } & \multicolumn{3}{c}{ Post-attitude } & \multicolumn{3}{c}{ Attitude change } & \multicolumn{3}{c}{ Booking intention } \\
\cline { 2 - 10 } & TRS & SNS & t-value & TRS & SNS & t-value & TRS & SNS & t-value \\
\hline No Response & 2.58 & 3.26 & $-2.09^{* *}$ & -2.98 & -2.35 & -1.24 & 2.13 & 2.82 & $-1.95^{*}$ \\
Accommodative & 3.02 & 3.64 & -1.46 & -2.26 & -2.01 & -.58 & 2.47 & 3.22 & $-1.83^{*}$ \\
Defensive & 2.97 & 3.86 & $-2.13^{* *}$ & -2.78 & -1.89 & -1.64 & 2.83 & 3.09 & -.54 \\
\hline $\begin{array}{l}\text { Note: TripAdvisor (TRS), Twitter } \\
\text { differences in booking intention for 'no response' strategy that were significant on a 5\% level, and post- }\end{array}$ \\
$\begin{array}{l}\text { attitude differences for 'accommodative' response that were significant on a 10\% level. } \\
* * p<.05 ; * p<.1\end{array}$
\end{tabular}

